\title{
Guidance on the Conceptual Design of Sustainable Product-Service Systems
}

\author{
Chong-Wen Chen (10) \\ Department of Information Communication, Yuan Ze University, 135 Yuan-Tung Rd., \\ Taoyuan City 32003, Taiwan; cwc2016@saturn.yzu.edu.tw or journalncku@yahoo.com.tw; \\ Tel.: +886-915-626-327
}

Received: 26 April 2018; Accepted: 12 July 2018; Published: 13 July 2018

check for updates

\begin{abstract}
The product-service system (PSS) has great potential to promote the circular economy (CE) and sustainability. Recent studies have highlighted the importance of associating social values with sustainable PSS because social actors, including stakeholders, institutions, and communities, are the key to organizational innovation and behavior change. However, it is still not clear how companies can incorporate the social context into service strategies and co-create sustainable value with their stakeholders. Through overall discussions on related studies, this concept paper proposes theoretically based guidance for developing sustainable product-service offerings in the early planning phase. A case scenario of recycling is presented to demonstrate the operation of the proposed approach. The results suggest that companies should expand the scope of their understanding of customer problems beyond the product use. Engaging in social issues such as skill empowerment and job creation can generate long-term benefits and strengthen the brand image. In addition, working with communities and other enterprises via incentives or interactive activities can foster open innovation for $\mathrm{CE}$. The proposed approach serves to assist designers in handling more comprehensive contexts of sustainability and allow better preparations for resource integration in the early PSS design phase.
\end{abstract}

Keywords: social value; innovation; sustainability; customer context; value creation; product-service system

\section{Introduction}

The Circular Economy (CE) has great potential to promote sustainability because it creates economic value with closed material loops that minimize waste generation and energy consumption from the production and product use [1,2]. Products that fulfill CE principles are usually more environmentally friendly, easy to recycle/reuse, and have longer lifecycles. Many studies have focused on new product development or product redesign for CE. However, $\mathrm{CE}$ is a complex issue and involves the whole supply chain and customer behavior [3]. To turn linear production model into the circular flow, long-term collaboration among manufacturers, suppliers, clients, and other stakeholders should be built [4]. In other words, emphasizing lifecycle management alone is not enough for CE to drive the radical innovation to meet sustainability demands. Sustainability is defined as the balance among economic, environmental, and social systems [5]. Compared to the ecological issues, social issues such as social justice, labor rights, and communities are often ignored in CE research [6]. In addition, customer behavior is a crucial factor determining whether business models align with CE principles [3]. Regulation and policy issues should also be addressed to enhance CE and sustainable society $[7,8]$.

The product-service system (PSS) that uses service strategies to replace product ownership can reduce the waste of materials and resources [9]. Schemes such as product sharing, renting, and leasing are common ways to facilitate sustainable production and consumption. The PSS is therefore considered as a potential enabler of CE [10]. The concept of PSS has been discussed for over 
15 years, and many studies have demonstrated how it changes consumption patterns (see [11,12]). However, as mentioned, CE should incorporate social actors into its system so that circular business models can be developed in an innovative and effective way. In this context, PSS research is facing some challenges, including how a PSS considers not only clients but also employees and communities for social sustainability [13] and how companies cooperate with their customers and stakeholders for value co-creation [14].

Prior studies $[15,16]$ have reviewed many approaches regarding PSS design. Although the reduction of social impact is mentioned, there is a lack of further arguments concerning how social and institutional values can be associated with product-service offerings. A few of studies $[17,18]$ have dealt with social concerns such as safety and health care for PSS design, but there is still a need to connect these concerns with economic and environmental issues to handle more comprehensive contexts of sustainability. In other words, mutual influence and interrelatedness among economic, environmental, and social systems should be built to make integral and long-term changes towards sustainability [19]. Accordingly, the research questions of this paper include: (1) how companies broaden their visions of sustainability and build collaborative networks for value co-creation; and (2) how PSS design addresses mutual influence between different systems and improves the completeness of sustainable solutions.

To deal with the above issues, we propose guiding principles for designing sustainable PSS in the early planning phase. This concept paper is based on library research. Through theoretical discussions on related review articles and approach papers, we summarize key factors of sustainable PSS and incorporate them into the proposed guiding principles. This paper includes several parts. In addition to the Introduction and Conclusion, Section 2 reviews and clarifies important concepts of sustainability and services; Section 3 describes the methodology we use and then proposes guiding principles for PSS design; Section 4 uses a case scenario to demonstrate how the proposed approach can be applied; and Section 5 provides overall discussions about this paper.

\section{Product-Service Systems and Sustainability}

\subsection{Sustainability and Sustainable Development}

Sustainability emphasizes the interdependence of economic, ecological/environmental, and social systems [20]. These systems are recognized as the three essential dimensions of sustainability and have been recently discussed within the context of three pillars, i.e., profits, planet, and people [21]. Sustainability can be discussed from different perspectives. For example, some research regarded sustainability as a means that enhances economic growth while reducing the environmental impact from the production; this idea is known as "decoupling" which involves concepts such as eco-design and green product design (see [22,23]). In contrast, social sustainability focuses more on the social concerns such as human health and labor care. Such perspective addresses basic human issues including safety, equity, and education for the socio-economic development [20]. To avoid causing a bias toward a specific dimension, it is important to deal with causal relationships among the economy, environment, and society to achieve full sustainability. This vision is called balance of the Triple Bottom Line (TBL) [24].

Sustainable development (SD) is another term commonly used to interpret sustainability. According to the report of World Commission on Environment and Development (WCED) [25], $\mathrm{SD}$ is defined as "development that meets the needs of present generation without compromising the ability of future generation to meet their own needs." In other words, SD focuses on fundamental human needs and long-term planning considering the future generation. That is, the time perspective should be integrated into sustainability visions to ensure the effect and long-range influence of decision making [19]. In addition, Parris and Kates [26] separated SD into two aspects: "What is to be sustained?" and "What is to be developed?" They further indicated that people, economy, and society are three factors to be developed, and nature, life support, and community are those to be sustained. 
When discussing $\mathrm{SD}$, the institution is sometimes regarded as the fourth dimension of sustainability (see $[27,28]$ ). The institutional dimension was first introduced by the United Nations Conference on Environment and Development (UNCED) and referred to the operation of governmental organizations, institutional mechanisms, and political orientation [29]. More recently, the institutional perspective broadly implies legislation, human interactions, and cross-sector cooperation. Because this dimension mainly operates in the context of public sectors, it has barely been discussed in a business framework. However, as SD is aimed to sustain long-term development of communities, organizations, and society, the concept of institutional dimension may inspire companies to build and manage new relationships with the government or nonprofit organizations in order to achieve sustainability goals. In addition, regulations, incentives, and penalties should also be made to improve managerial efficiency of sustainability-led policies [7].

In summary, comprehensive sustainability concerns encompass long-term plans for economic development, environmental benefits, social well-being, and institutional improvement. Furthermore, the interrelationship between these dimensions should be established to clarify the full context of sustainability [30].

\subsection{Value Creation through Services}

The PSS can be defined as a set of products and services integrated into a system to meet customer needs [31]. This definition shows three main factors of PSS, namely products, services, and satisfaction. Generally, products are considered as physical and marketable properties while services are regarded as intangible activities [32]. There is no certain rule to define how products and services interact to deliver satisfaction in a PSS, but past studies have summarized three types of PSS: (1) product-oriented PSS; (2) use-oriented PSS; and (3) result-oriented PSS (see [33]). The product-oriented PSS considers services as added value (e.g., repair and maintenance services) that enhances product sales. The use-oriented PSS and result-oriented PSS take services as the main solutions, where customers enjoy the functionality of products or the result of services rather than the product ownership. These strategies can help foster CE. For example, product-oriented PSS such as repair or maintenance is applied to extend the product life cycle. Use-oriented PSS such as leasing or renting scheme assists companies in handling the process of product use and deciding when products should be repaired, recycled, or remanufactured [34]. However, PSS strategies do not necessarily lead to sustainable solutions. For example, the so-called rebound effect occurs when customers overuse eco-friendly products [34,35]. In addition, PSS should also consider social values and socio-economic development to ensure the balance of TBL [36]. That is, social practices (e.g., job creation or community empowerment) and their activators (e.g., legislation or reward) are important elements for the design of sustainable PSS.

Many studies (e.g., [37-39]) have indicated that value propositions determine how services deliver satisfaction and values to the stakeholders. Clarifying different types of value helps understand the structure of PSS. Vargo et al. [40] has introduced two types of value, value-in-exchange and value-in-use. The former emphasizes the firm's output and price; it creates the advantage for the company and its customers via the exchange of goods and money. The latter indicates that value creation occurs only when customers use the products. Value-in-exchange implies that product sales are the prime revenue channels for companies while services are subsidiaries that add value to products. Add-on services such as free home delivery, guarantee extension, and repair can create feedback and extra value on products. In contrast, value-in-use turns product sales into functional sales or operational services, where customers only pay for the use/operation of products rather than buying the products. It offers the opportunity to decouple economic success from material consumption [41].

For sustainability issues, the concept of value-in-use mainly helps reduce the environmental impact from economic activities. To incorporate social well-being into the PSS, we need to understand the lifestyles and a large context behind customers and stakeholders. The idea of value-in-context engages customers' hidden needs in a deeper way (see [42]). Take a meat supplier as an example. In addition to meat delivery services, the supplier can offer cooking services that turn its products 
(i.e., meat) into a further solution (i.e., delicious dishes that satisfy customers). Providing delicious dishes via cooking services reveals a larger context of problem solving than directly selling raw meat does. If customers prefer cooking themselves, they will need knowledge of using kitchen appliances as well as cooking skills to enhance their works. By recognizing such context, the meat supplier can offer teaching services concerning improving customers' cooking skills. Accordingly, these offerings generate value built upon the context of problem solving, including the operation across various appliances, knowledge involved, and customers' preferences and lifestyles. Such concept has gone beyond value-in-use that mainly focuses on the use of a specific product. Table 1 presents the relationship between the three types of value in product-service offerings.

Table 1. Comparison of different value types. Data are adapted from [43].

\begin{tabular}{cccc}
\hline & Value-in-Exchange & Value-in-Use & Value-in-Context \\
\hline Value generation & Value-added & Co-production & Co-creation \\
Factor of satisfaction & Products & Offerings & Experiences \\
Level of provision & Attributes & Benefits & Solutions \\
\hline
\end{tabular}

As shown in Table 1, value-in-context has brought services to a solution level that meets life experiences of customers. Solution-based services require more interaction between the company and customers. Early involvement with customers is essential to achieve solutions that respond to customers' real needs [41]. Such interaction and involvement often require collaboration (e.g., information delivery or sharing) that makes the company and customers co-create value [44]. Education programs or training services are examples of value co-creation because they not only increase profitability and brand value for the company but also aid customers in acquiring capabilities to get their tasks done or enrich their lives. Customized offerings and participatory design can also help companies make direct and long-term contact with customers [45]. To deliver desirable solutions to customers, companies should identify the clues hidden in the context of customers' lives. Value-in-context inspires companies to recognize customers' lifestyles first and then build service offerings to satisfy customers. Accordingly, such services may require broader and multiple strategies. Because customer solutions here are not limited to the product use, they could be complicated and involve different techniques and capacities out of companies' resources. Open innovation might be needed to cooperate with other companies, partners, or the government; it provides opportunities to facilitate social development, find new space for organizational innovation, and co-create sustainable value with the stakeholders [46].

In summary, the key to designing sustainable PSS is to connect value network between different stakeholders and embed sustainability visions into the service context. New partnerships among producers/suppliers, customers, public sectors, and volunteer association should be developed [34]. To do so, an approach to identifying value propositions and fostering divergent thinking for PSS designers would be needed. The next section presents guiding principles for conceptualizing sustainable values in the PSS.

\section{Guiding Principles for Designing Sustainable Product-Service Systems}

\subsection{Methodology}

Because this paper is dedicated to a conceptual study, we utilized library research to summarize crucial knowledge of sustainable PSS. We began with observation of related studies, and then analyzed common ground and differences between the selected references and indicate important factors that should be considered in the PSS design phase. In addition to general PSS studies, we consulted PSS review articles and papers regarding PSS design approaches. Review articles usually provide comprehensive information and knowledge of past studies and show barriers and pathways toward future research, thus being proper references for library research. 
Many PSS studies applied the Scopus database to select references for their analysis (e.g., [15, 47]). We followed this method and searched related papers. Only peer-reviewed journal papers were considered. For review articles, we used keywords including "product-service systems" and "PSS". We then checked whether search results are related to sustainability issues. For approach papers, we added keywords such as "design", "approach", and "framework". PSS methodologies are threefold: design, evaluation, and operation methodologies [15]. We mainly considered the design methodology, especially the idea development for PSS planning. Finally, we selected seven review articles $[15,16,41,47-50]$ and eight approach papers $[14,17,18,51-55]$ for further analysis. We proposeed theoretically based guidance for PSS design according to the summary of these selected papers.

\subsection{Key Factors of Sustainable PSS}

In Section 2, we have pointed out several important issues of sustainable PSS such as social values, institutional/governmental improvement, and value co-creation. We associated these issues with the selected articles (see Table 2).

Table 2. Key factors of sustainable PSS highlighted in past studies.

\begin{tabular}{|c|c|c|c|}
\hline Categories & Key Factors & Review Articles & Approach Articles \\
\hline Customer perspectives & $\begin{array}{c}\text { Customer perception, } \\
\text { Customer acceptance, } \\
\text { Customization, } \\
\text { Customer involvement/interaction. }\end{array}$ & {$[15,16,41,47,48,50]$} & {$[14,51,53-55]$} \\
\hline Stakeholder networks & $\begin{array}{l}\text { Partnership/collaboration, } \\
\text { Value co-creation, } \\
\text { Organizational change. } \\
\text { Life cycle management, }\end{array}$ & {$[15,50]$} & {$[14,51-55]$} \\
\hline Environmental values & $\begin{array}{l}\text { Material/resource reduction, } \\
\text { Energy efficiency, } \\
\text { Reduction in consumption. }\end{array}$ & {$[15,16,41,47-50]$} & {$[17,18,51,52,54]$} \\
\hline Social values & $\begin{array}{c}\text { Health/safety care, } \\
\text { Employee care, } \\
\text { Social and cultural change, } \\
\text { Welfare. }\end{array}$ & {$[16,48]$} & {$[17,18,52]$} \\
\hline Institutional engagement & $\begin{array}{c}\text { Policy and regulation/legislation, } \\
\text { Administration. }\end{array}$ & [48] & {$[17,53]$} \\
\hline Visualization methods & $\begin{array}{l}\text { Stakeholder information, } \\
\text { Value network, } \\
\text { Product-service offerings, } \\
\text { Service interface. }\end{array}$ & [15] & {$[14,17,51,53-55]$} \\
\hline
\end{tabular}

In Table 2, we summarize six categories that contain multiple factors of PSS research and design. The article counts if it puts any key factor in its arguments. Almost all articles highlight customer perspectives and environmental benefits, especially the improvement of product life cycles. Customer acceptance determines whether a PSS can be fulfilled [41,48]. In other words, it is important to change customer thinking and attitudes through desirable offerings. In addition, increasing interaction with customers and even combining user involvement with the PSS design process can help foster customer acceptance and value co-creation [14]. Stakeholder networks built by partnership and alliances can also realize value co-creation (see $[50,54]$ ). To do so, almost all approach articles apply visualization methods to develop and present stakeholder information and its value networks.

Although we have argued that social and policy issues should be engaged in sustainable PSS design, only few articles address social values and institutional engagement. For the review articles (see $[16,48]$ ), the reduction of social impact is mentioned, but they do not provide further arguments regarding how and what social values can be embedded in a PSS. For the approach articles (see $[17,18,52])$, they give more tangible examples (e.g., health and safety care) concerning the linkage between PSS and social sustainability. Generally, product-centric companies create revenues based on their product sales. How customers can better use the products is their main consideration. 
Therefore, in traditional PSS strategies, service offerings are often developed based on the product use. Joore and Brezet [17] provided a different point of view by starting PSS design with the analysis of social problems. This scheme assists designers in addressing the process of social change. It also requires regulation and legislation to fulfill the institutional improvement. To develop comprehensive solutions, Maxwell and van der Vorst [18] used the TBL context to clarify problems in the three dimensions of sustainability.

The above contributions provide clues for designing a sustainable PSS, including cooperating with stakeholders and customers for value co-creation, using visualization methods to build value networks, and dealing with not only the problems of product use but also social and institutional concerns in the TBL context. On the other hand, visualization methods present stakeholder networks and how product-service offerings are delivered, but there is a lack of a tangible approach to idea generation for the early PSS planning phase. Thus, it is necessary to combine idea generation techniques with visualization methods.

\subsection{Guidelines for PSS Design}

Finding and defining the problems is the first step of design [56]. Following Joore and Brezet [17], we suggest that PSS designers could define the problems that go beyond the scope of companies' existing products. If companies decide to capture more value from sustainability efforts, they should recognize a larger context behind general customer needs; social issues such as health care and labor right can be involved here.

To stimulate the idea generation of PSS design, inductive teaching and learning methods can be consulted. Such methods are applied to motivate learners and their thinking, presenting a challenge, such as a case to be analyzed or a real-world problem, to be solved [57]. The effect is especially significant in engineering education [58]. Inquiry learning, as a simple inductive approach using questions and problems to provide contexts, is suitable for interactive lectures, discussion, and service learning $[57,59]$. Therefore, we suggest integrating inquiry learning with sustainability knowledge to advance concept generation and the communication between PSS designers. Based on this understanding and the summary of previous subsection, we propose four-step guiding principles to help designers create PSS offerings in the early planning phase (see Table 3 ).

Value propositions determine how companies create environmental and social benefits through their offerings [60]. These propositions are based on what kinds of problems companies want to deal with. If companies would like to extend their influences on socio-economic development and CE, they should broaden the scope of selected issues in the first step. As stated, a sustainable PSS requires a collaborative network to address complicated requirements and social needs. The second and third steps serve to explore more PSS ideas by connecting various problems across sectors and different sustainability dimensions. Resource integration in the fourth step can be thus clarified according to the results of the third step. 
Table 3. Guiding principles for PSS design in the planning phase.

\begin{tabular}{|c|c|c|c|c|}
\hline & Steps & & Tasks & Notes \\
\hline (1) & Find the problems & C. & $\begin{array}{l}\text { Select an issue that fails to meet the } \\
\text { sustainability requirements. } \\
\text { Describe all problems associated with } \\
\text { this issue. } \\
\text { List the problems under the TBL context. }\end{array}$ & $\begin{array}{l}\text { A complex issue could involve multiple } \\
\text { problems. List them in order to handle a } \\
\text { comprehensive context of sustainability. } \\
\text { Broaden the scope of selected issue beyond } \\
\text { the product use in order to formulate new } \\
\text { value propositions for the company. }\end{array}$ \\
\hline (2) & Recognize the context & B. & $\begin{array}{l}\text { Explore the relationships of all } \\
\text { listed problems. } \\
\text { Link the problems to generate a network of } \\
\text { causal relationships. }\end{array}$ & $\begin{array}{l}\text { The causal relationships show mutual } \\
\text { influence between different dimensions of } \\
\text { sustainability and help clarify the order of } \\
\text { problem solving. }\end{array}$ \\
\hline (3) & Explore the possibility & A. & $\begin{array}{l}\text { Classify highly related problems into a group } \\
\text { and propose inquiries for these problems in } \\
\text { each group. } \\
\text { Seek out whether there are solutions used to } \\
\text { deal with these problems. }\end{array}$ & $\begin{array}{l}\text { Each inquiry group gathers problems that } \\
\text { have similar or related attributes, thus } \\
\text { helping designers formulate systematical } \\
\text { solutions. }\end{array}$ \\
\hline (4) & Built the network & A. & $\begin{array}{l}\text { Summarize the proposed questions into } \\
\text { several keywords and link their relationships. } \\
\text { Define potential participants/partners and } \\
\text { ideal goals for new solutions according to the } \\
\text { organized keywords. }\end{array}$ & $\begin{array}{l}\text { The network should contain both the } \\
\text { short-term and long-term goals of } \\
\text { product-service offerings. }\end{array}$ \\
\hline
\end{tabular}

\section{A Case Scenario}

We used a case scenario to demonstrate how the proposed principles can be applied to facilitate sustainable PSS design. We took a recycling scenario as a starting point to illustrate how sustainability thinking relates product-service concepts to innovation. This scenario is based on the case study of waste pickers, and researchers have summarized comprehensive data via questionnaires, in-depth interviews, and field studies to present the structure of waste pickers and recycling mechanisms [61]. Figure A1 uses graphic presentation with descriptive information to present the recycling scenario. This case was selected because it involved a complex system including recycling behavior, consumer awareness, policies, environmental benefits, and socio-economic development.

To demonstrate the operation of the proposed approach, an academic workshop was carried out with ten participants including master and doctoral students in industrial design. Participants were asked to design a PSS model for the Company $\mathrm{X}$ which is a production company manufacturing commodities such as stationery, housewares, and hygiene products. Company $\mathrm{X}$ has its own brand and runs several factory outlets in the country. This company would like to use new product-service offerings to expand its core business and create sustainable value.

The workshop participants explore possible PSS ideas via group discussions, based on the data of case study and their own observations on recycling behavior. The proposed guiding principles were utilized to facilitate their brainstorming.

\subsection{Operation of the Guiding Principles}

As shown in Figure 1A, this scenario involves three roles, including waste pickers, residents, and recycling centers. The first step is to identify problems related to the recycling issue. The case study has indicated several major problems that fail to meet the sustainability requirements. For example, waste pickers spent long time on collecting materials while they earned tiny income. This was a normal situation because waste pickers did not have cars or motorcycles and recycling centers often made unfair trade. In addition, the workshop participants observed that consumers/residents lacked awareness and thus resulted in inefficiency of recycling. These problems are listed under the TBL dimensions in Figure 1. 

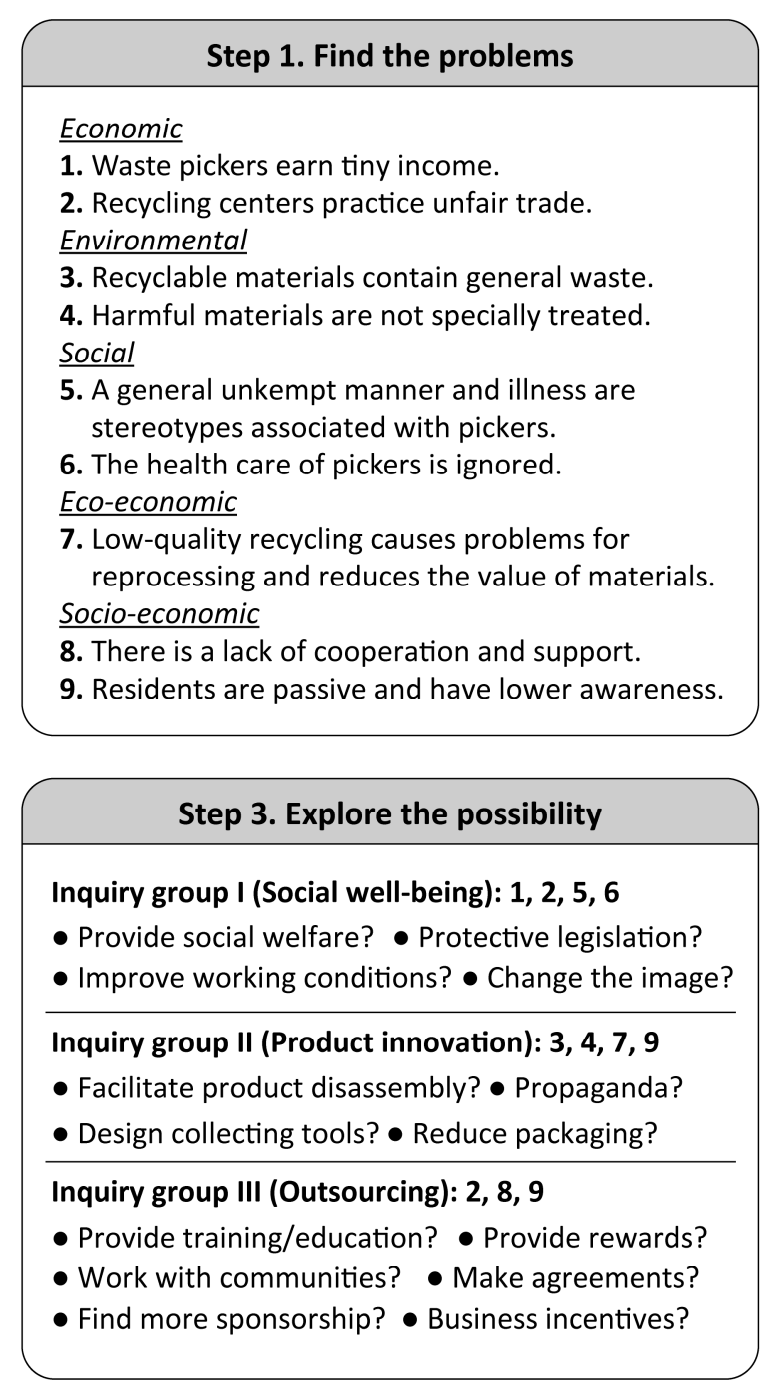
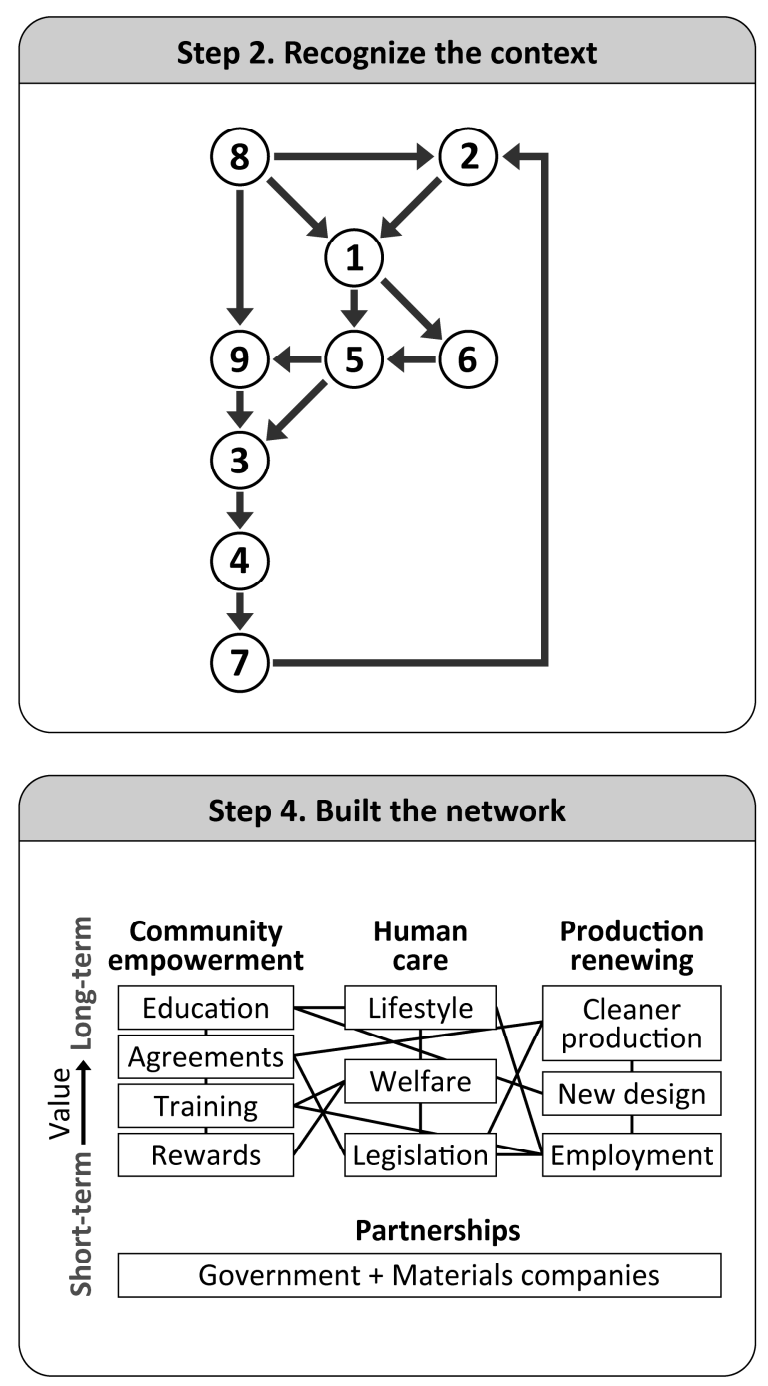

Figure 1. Applying guiding principles to embed sustainability contexts into the PSS design.

Although the TBL is used to classify the problems from different dimensions, some problems are located in overlapping areas (e.g., eco-economic and social-environmental). In fact, all the problems are not fully independent, and most of them have cause-effect relationships. For example, recycled materials often contained general waste because of residents' lack of awareness. Lower economic value of collected materials also drove recycling centers to practice unfair trade. In other words, if residents' thinking and behavior can be changed, the value of recycled materials will be enhanced and the recycling trade will be improved. To understand the complete context of this issue, designers should clarify the cause and effect relationship between these problems in the second step. Problems with close attributes could be put into a group that indicates what value propositions the company might take. Tool such as Interpretive Structural Modeling (ISM) (see [62]) could help build this context if the connections between different problems were complex.

For Step 3, designers can propose hypotheses regarding each inquiry group. These inquiries are used to explore more possibilities of product-service offerings. The more inquiries designers arouse, the more space of innovation can be found. For example, the inquiry group of outsourcing (i.e., group III) in Figure 1 is important because it contains key driving factors (i.e., the cause of recycling problems) shown in Step 2. These inquiries are proposed with the intention to change residents' behavior and prevent unfair trade. Addressing these inquiries has gone beyond the company's competence; thus, it requires outsourcing or collaboration with different sectors. Designers can then search for a series of solutions based on the proposed inquiries. The results of current research could be consulted. 
For instance, the "name and shaming" strategy and serious penalties are considered to be positive for waste services [7]. Incentives such as rewards or building cooperative business centers for collecting city waste are also helpful for increasing recycling efficiency (see [63]). These potential solutions assist designers in addressing their inquiries.

Finally, the possible solutions are organized into representative keywords that indicate relative knowledge domains. Designers can search for corresponding offerings from the key fields. For example, legislation and welfare can be discussed from the perspective of public administration and the new product design or education for community empowerment can consult experts in industrial design. Additionally, keywords sharing similar characteristics can be summarized as an ideal goal of innovative strategy. The goals show both short-term and long-term values all participants co-created. As the information has been developed, the stakeholders and their relationships in the mechanism can be identified. At the moment, new partnerships are engaged to run service structures for system-based solutions.

\subsection{Results and Interpretation}

New product-service offerings developed in the case scenario are shown in Figure 2. In this scenario, we start with Company $\mathrm{X}$ which intends to develop new PSS offerings and create sustainable value. Here, Company $\mathrm{X}$ works with other materials companies as well as the local government and offers waste pickers and customers incentives to improve the efficiency of recycling. This system contains multiple product-service offerings. Company X offers customers residential recycling services, skill empowerment services, and repair services. Recycling services deal with product disposal while empowerment services help customers, especially housewives, to create novel products/artworks using abandoned materials. Waste pickers are also involved in manufacturing the recycled materials into new products, and the government offers them health care and medical services.

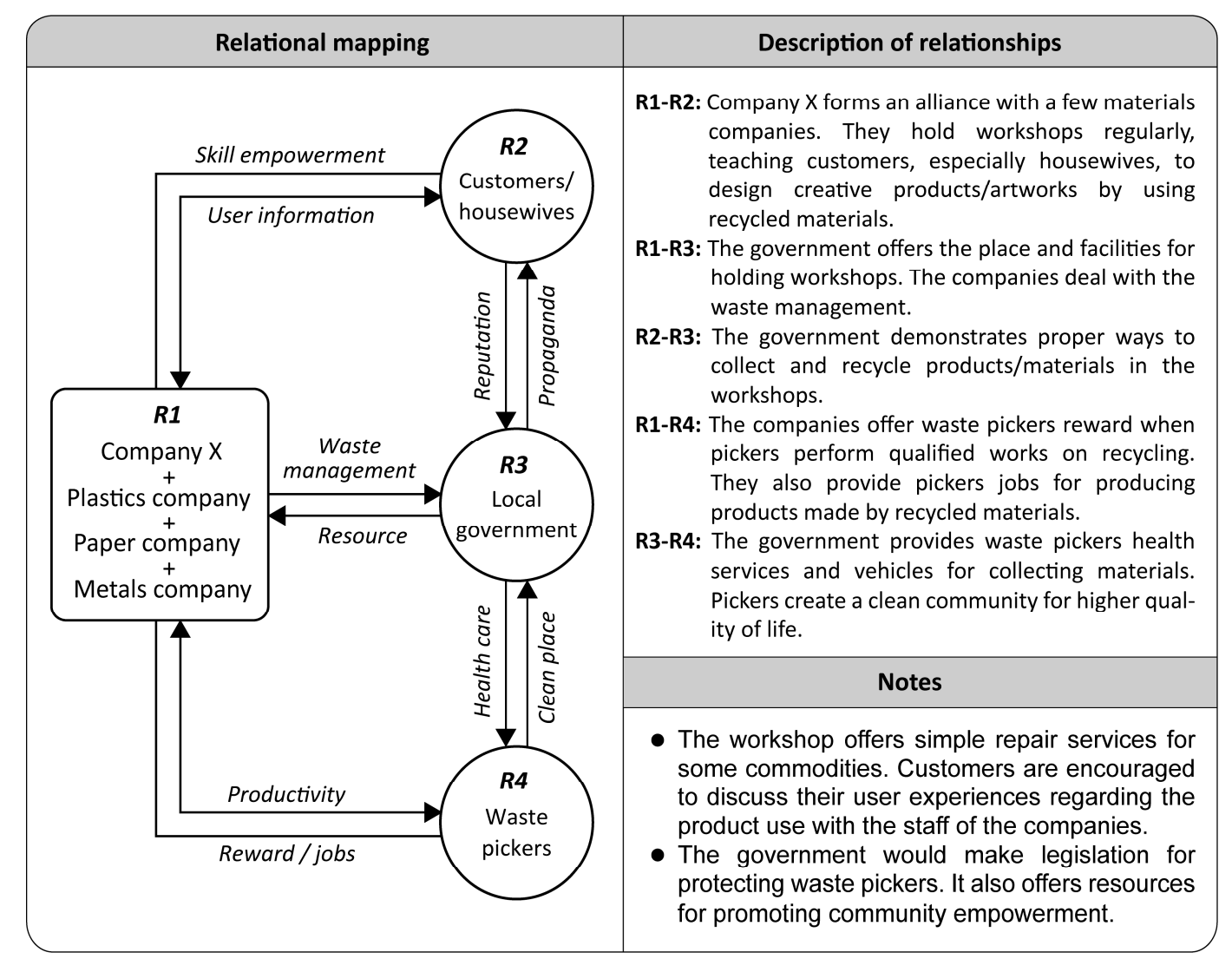

Figure 2. Case scenario of the new product-service system. 
In this case, all actors co-create sustainability values when they interact. For example, customers such as housewives are able to create value after learning the knowledge and design skills regarding product reuse/redesign. Companies demonstrate their value propositions of social care by providing welfare and skill empowerment services as well as their environmental value propositions by managing recycling and repair services. The government promotes institutional values as it is devoted to legislation and health care issues. Waste pickers join the production and fulfill the social practice. Costumers are educated not only to reuse recycled materials but also to classify materials properly. Furthermore, since different companies forge an alliance and work with the community closely, they have more chances to manage the product life cycle and advance the efficiency of material use. That is, all actors help enhance waste management for the environment.

In traditional business models, companies focus more on how customers use their products. However, in this scenario, Company $\mathrm{X}$ expands its considerations and highlights how customers enrich their lives by learning and applying design skills to deal with recycled materials. As shown in Figure 2, using recycled materials to create necessities or artworks demonstrates a new way of design and a new lifestyle. Actually, creative products made of abandoned materials have great capacity to compete with products using only virgin materials [64]. In addition, when Company $X$ provides empowerment services, it is a great opportunity to understand how customers use their products and what kinds of functionality should be adjusted or modified. Moreover, this case also addresses social benefits by providing waste pickers reward and jobs. Such out-of-the-box thinking and sustainability-led values can enhance the brand image for the company.

The PSS solutions in this case are mainly based on the perspective of Company X. From the methodological point of view, other stakeholders in this scenario can be the PSS designers too. For example, if the local government wants to raise nonprofit services, it can consult similar value network and work with various enterprises to improve the recycling behavior. Then, its focus will be regulatory and policy-making aspects. To develop the value network, the delivery and feedback of value should be visualized. As shown in Figure 1, depicting the problems in hierarchical charts and inquiry groups can help designers conceptualize different types of sustainability values. If researchers or managers would like to elaborate the details of PSS or perform service evaluation, they can conduct quantitative analysis and add numerical information such as weights or risk coefficient on each factor of the charts. In summary, the proposed guiding principles can generate a blueprint for value co-creation and allow preparations for the shift from service ideas to comprehensive system solutions.

\section{Discussions}

Many PSS design methodologies start with the analysis of product use and customer satisfaction and then develop services for improving product life cycles or replacing product sales. This scheme can reduce material waste and resource consumption, but it somehow limits PSS solutions to the scope of environmental considerations. Broader visions of sustainability should be cultivated to extend the influence of PSS from pure "cleaner and greener" improvements to socio-technical changes [65]. Actually, solving social problems and seeking social value generation can lead companies to an increase in the size of market and profits [66]. Community-based PSS solutions can even enhance poverty alleviation and employment generation for social development [67]. Therefore, the proposed approach takes reverse thinking by addressing a broad range of sustainability issues first and then discovering the opportunity of product-service offerings accordingly. In other words, it has the capacity to meet more social and institutional concerns.

Moreover, the interrelatedness among economic, environmental, and social systems plays a key role in long-term changes towards sustainability [19]. To ensure the completeness of PSS solutions, we explored the cause-effect relationships across different systems. These relationships are the base of collaborative problem solving. Visualizing these relationships aids companies in determining the direction of value propositions and generating a blueprint containing the short-term and long-term development pathways, as well as potential participants with possible resource support. 
In service research, a basic question that must be answered for concept generation is "What is offered and how it is offered?" [68]. Answering this question would aid companies in linking their strategic intent to service needs [69]. In addition, identifying people, physical facilities, and processes is a necessary task for clarifying value deliveries [70]. Research also indicated that crucial factors for designing more circular services included value propositions, resources and capabilities, revenue models, and customer interfaces [71]. These contributions have implied three main concerns of the value network: (1) what kinds of values the stakeholders would co-create; (2) which participants would join in this network; and (3) how stakeholders share their resources and interact with each other. The proposed guiding principles with the visualization method and inquiry learning help designers face these questions.

Pervasive shift in consumer behavior is the core of sustainable consumption [3]. Service offerings connecting with social actors should be developed to influence people's thinking. Schemes for changing customer behavior can be mandatory or encouraging. Mandatory force such as regulation with penalties and legal mechanism have great potential to promote waste services [7,65]. Making an alliance with other companies and the government also helps develop more comprehensive mechanisms. As for incentives and encouragement, training and education programs are great services to aid customers in solving problems and creating long-term value. Providing ample information through education services has been proved to be effective in changing consumer behavior [72]. With the group influence, the power of education can be even stronger. One the other hand, services can be designed as an amusing activity and attractive incentives for raising consumer awareness of environment issues. For example, The Fun Theory presented several cases on environmental protection, showing the possibility of changing human behavior via interactive and playful products or services (see [73]). Companies can regard service offerings as an interactive activity and customers as players. Psychological or marketing skills may aid in designing interesting offerings for motivating players.

\section{Conclusions}

Many companies today aim to associate their sustainability visions with product-service offerings. Traditional PSS cases and CE principles focused more on the life cycle management issues. How social values can be incorporated in business strategies are relatively ignored. In addition, there is a lack of guidance for generating PSS ideas based on the integral context of sustainability. Therefore, our research questions were: (1) How do companies broaden their visions of sustainability and build collaborative networks for value co-creation? (2) How does PSS design address mutual influence among the economic, environmental, and social systems and improve the completeness of sustainable solutions? We have explored key factors of sustainable PSS and proposed operational principles to deal with these questions. We use the TBL context to broaden companies' considerations of sustainability-led services and apply the visualization method to help develop collaborative value networks. We also utilize the inter-linkage concept to foster systems thinking and the inquiry learning to stimulate idea generation for more integral contexts and solutions.

Important implications for companies and researchers include: (1) to think out of the box, companies should expand the scope of their understanding of customer problems beyond the product use; (2) incentive regulation and interactive activities generating feedback for stakeholders are effective tactics for behavior change; (3) addressing social issues may not bring immediate economic profit, but it will generate long-term values and enhance the brand image for companies; and (4) developing collaborative networks with the government, communities, and other social actors can foster open innovation and find more opportunities to co-create sustainable values.

Because this concept paper is based on library research, there are several limitations regarding the proposed approach. First, the references we analyze were selected from journal papers in the Scopus database, but other conference papers or case reports may also contain important information. Secondly, the inquiry learning can help generate multiple PSS ideas, but it lacks quantitative analysis to evaluate the feasibility of each idea. In addition, radical innovation often comes with risks. Field research 
concerning how companies manage risk analysis will be needed to ensure the stability of new PSS solutions. Moreover, although the proposed approach encourages the establishment of collaborative networks and open innovation, the fear of sharing sensitive information may become the barrier to collaboration-based PSS [74]. Managing companies' intellectual property in shared value networks can be another complicated issue for future research.

Funding: This research received no external funding.

Acknowledgments: We want to thank Chun-Juei Chou for his support and guidance. We are also grateful to all academic workshop participants. Additionally, we want to thank the Guest Editor of the Special Issue, Stefano Pascucci, and anonymous reviewers, for their valuable comments that help improve the quality of this paper.

Conflicts of Interest: The author declares no conflict of interest.

\section{Appendix A}

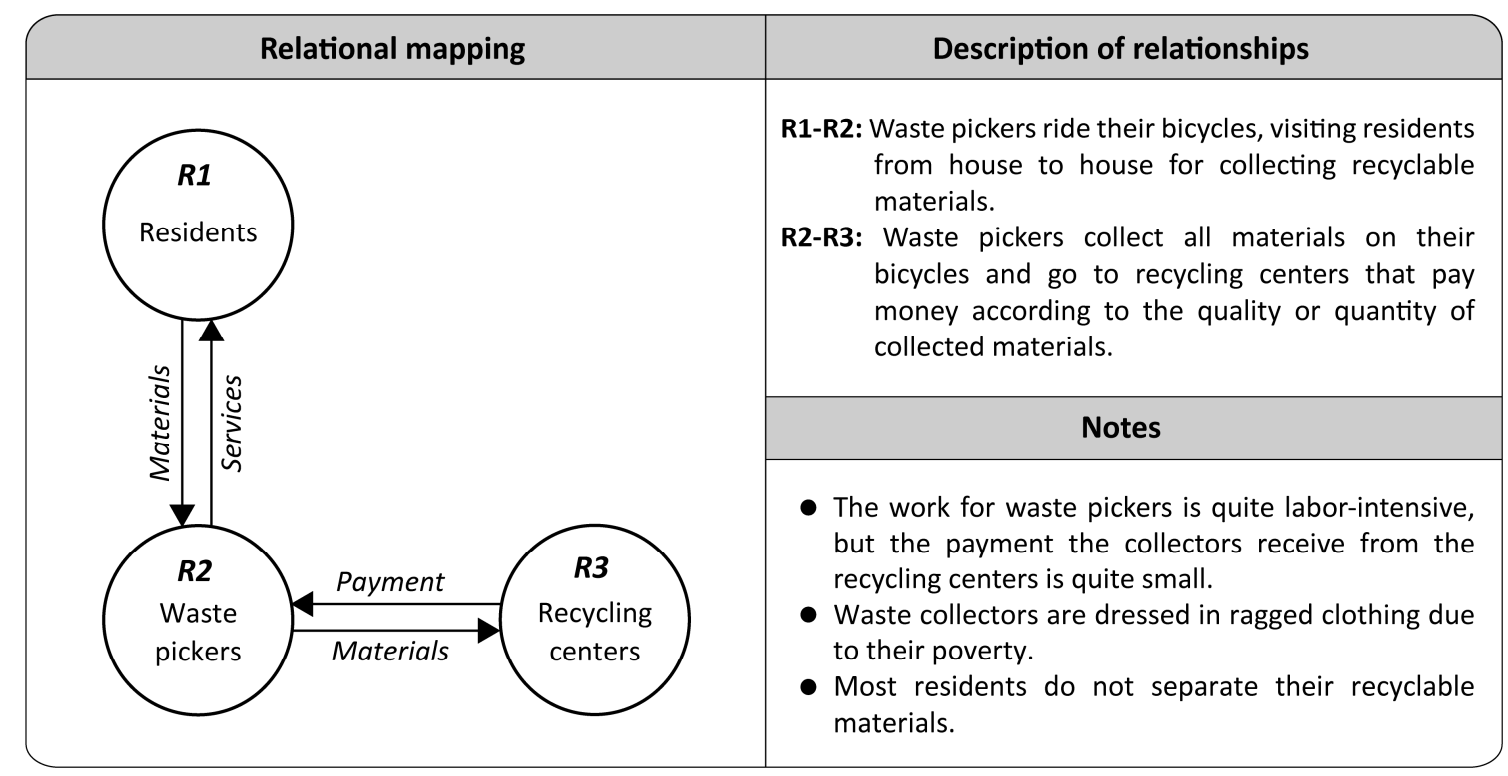

Figure A1. Graphic presentation of the recycling scenario. The case was adopted from [61].

\section{References}

1. Geissdoerfer, M.; Savaget, P.; Bocken, N.M.P.; Hultink, E.J. The circular economy-A new sustainability paradigm? J. Clean. Prod. 2017, 143, 757-768. [CrossRef]

2. Linder, M.; Williander, M. Circular business model innovation: Inherent uncertainties. Bus. Strategy Environ. 2017, 26, 182-196. [CrossRef]

3. Planing, P. Business Model Innovation in a Circular Economy Reasons for Non-Acceptance of Circular Business Models. Open J. Bus. Model Innov. 2015, in press.

4. Vrijhoef, R. Supply Chain Integration in the Building Industry: The Emergence of Integrated and Repetitive Strategies in a Fragmented and Project-Driven Industry; Ios Press: Clifton, VA, USA, 2011.

5. Elkington, J. Triple bottom-line reporting: Looking for balance. Aust. CPA 1999, 69, 18-21.

6. Murray, A.; Skene, K.; Haynes, K. The circular economy: An interdisciplinary exploration of the concept and application in a global context. J. Bus. Ethics 2015, 140, 369-380. [CrossRef]

7. Simoes, P.; Marques, R.C. On the economic performance of the waste sector. A literature review. J. Environ. Manag. 2012, 106, 40-47. [CrossRef] [PubMed]

8. Charter, M.; Keiller, S. Grassroots Innovation and the Circular Economy; The Centre for Sustainable Design®University for the Creative Arts: Farnham, UK, 2014. 
9. Tukker, A.; Tischner, U. Product-services as a research field: Past, present and future. Reflections from a decade of research. J. Clean. Prod. 2006, 14, 1552-1556. [CrossRef]

10. Kjaer, L.L.; Pigosso, D.C.A.; Niero, M.; Bech, N.M.; McAloone, T.C. Product/service-systems for a circular economy: The route to decoupling economic growth from resource consumption? J. Ind. Ecol. 2018. [CrossRef]

11. Cook, M.B.; Bhamra, T.A.; Lemon, M. The Lsfer and application of product service systems: From academia to UK manufacturing firms. J. Clean. Prod. 2006, 14, 1455-1465. [CrossRef]

12. Williams, A. Product service systems in the automobile industry: Contribution to system innovation? J. Clean. Prod. 2007, 15, 1093-1103. [CrossRef]

13. Chou, C.-J.; Chen, C.-W.; Conley, C. An approach to assessing sustainable product-service systems. J. Clean. Prod. 2015, 86, 277-284. [CrossRef]

14. Tran, T.; Park, J. Development of a novel co-creative framework for redesigning product service systems. Sustainability 2016, 8, 434. [CrossRef]

15. Qu, M.; Yu, S.; Chen, D.; Chu, J.; Tian, B. State-of-the-art of design, evaluation, and operation methodologies in product service systems. Comput. Ind. 2016, 77, 1-14. [CrossRef]

16. Vasantha, G.V.A.; Roy, R.; Lelah, A.; Brissaud, D. A review of product-service systems design methodologies. J. Eng. Des. 2012, 23, 635-659. [CrossRef]

17. Joore, P.; Brezet, H. A multilevel design model: The mutual relationship between product-service system development and societal change processes. J. Clean. Prod. 2015, 97, 92-105. [CrossRef]

18. Maxwell, D.; van der Vorst, R. Developing sustainable products and services. J. Clean. Prod. 2003, 11, $883-895$. [CrossRef]

19. Lozano, R. Envisioning sustainability three-dimensionally. J. Clean. Prod. 2008, 16, 1838-1846. [CrossRef]

20. Hutchins, M.J.; Sutherland, J.W. An exploration of measures of social sustainability and their application to supply chain decisions. J. Clean. Prod. 2008, 16, 1688-1698. [CrossRef]

21. Kemp, R.; Martens, P. Sustainable development: How to manage something that is subjective and never can be achieved. Sustain. Sci. Pract. Policy 2007, 3, 5-14. [CrossRef]

22. Clark, G.; Kosoris, J.; Hong, L.N.; Crul, M. Design for sustainability: Current trends in sustainable product design and development. Sustainability 2009, 1, 409-424. [CrossRef]

23. Stamm, A.; Dantas, E.; Fischer, D.; Ganguly, S.; Rennkamp, B. Sustainability-Oriented Innovation Systems: Towards Decoupling Economic Growth from Environmental Pressures? Deutsches Institut für Entwicklungspolitik: Bonn, Germany, 2009.

24. Elkington, J. Cannibals with Forks: The Triple Bottom Line of 21st Century Business; Calstone Publishing Limited: Oxford, UK, 1997.

25. World Commission on Environment and Development (WCED). Our Common Future; Oxford University Press: New York, NY, USA, 1987.

26. Parris, T.M.; Kates, R.W. Characterizing and measuring sustainable development. Annu. Rev. Environ. Resour. 2003, 28, 559-586. [CrossRef]

27. Sharifi, A.; Murayama, A. A critical review of seven selected neighborhood sustainability assessment tools. Environ. Impact Assess. Rev. 2013, 38, 73-87. [CrossRef]

28. Valentin, A.; Spangenberg, J.H. A guide to community sustainability indicators. Environ. Impact Assess. Rev. 2000, 20, 381-392. [CrossRef]

29. Spangenberg, J.H.; Pfahl, S.; Deller, K. Towards indicators for institutional sustainability: Lessons from an analysis of agenda 21. Ecol. Indic. 2002, 2, 61-77. [CrossRef]

30. Lozano, R. Developing collaborative and sustainable organisations. J. Clean. Prod. 2008, 16, 499-509. [CrossRef]

31. Goedkoop, M.J.; van Halen, C.J.G.; te Riele, H.R.M.; Rommens, P.J.M. Product Service Systems, Ecological and Economic Basics. Report for Dutch Ministries of Environment (VROM) and Economic Affairs (EZ). 1999. Available online: https://www.researchgate.net/publication/293825611_Product_Service_systems_ Ecological_and_Economic_Basics (accessed on 12 July 2018).

32. Lovelock, C.; Gummesson, E. Whither services marketing? In search of a new paradigm and fresh perspectives. J. Serv. Res. 2004, 7, 20-41. [CrossRef]

33. Tukker, A. Eight types of product-service system: Eight ways to sustainability? Experiences from suspronet. Bus. Strategy Environ. 2004, 13, 246-260. [CrossRef] 
34. Manzini, E.; Vezzoli, C. A strategic design approach to develop sustainable product service systems: Examples taken from the 'environmentally friendly innovation' italian prize. J. Clean. Prod. 2003, 11, 851-857. [CrossRef]

35. Mestre, A.; Vogtlander, J. Eco-efficient value creation of cork products: An lca-based method for design intervention. J. Clean. Prod. 2013, 57, 101-114. [CrossRef]

36. Ceschin, F. Critical factors for implementing and diffusing sustainable product-service systems: Insights from innovation studies and companies' experiences. J. Clean. Prod. 2013, 45, 74-88. [CrossRef]

37. Lewandowski, M. Designing the business models for circular economy-Towards the conceptual framework. Sustainability 2016, 8, 43. [CrossRef]

38. Azcarate-Aguerre, J.F.; Den Heijer, A.C.; Klein, T. Integrated facades as a product-service system: Business process innovation to accelerate integral product implementation. J. Facade Des. Eng. 2017, 6. [CrossRef]

39. Barquet, A.P.B.; de Oliveira, M.G.; Amigo, C.R.; Cunha, V.P.; Rozenfeld, H. Employing the business model concept to support the adoption of product-service systems (pss). Ind. Mark. Manag. 2013, 42, 693-704. [CrossRef]

40. Vargo, S.L.; Maglio, P.P.; Akaka, M.A. On value and value co-creation: A service systems and service logic perspective. Eur. Manag. J. 2008, 26, 145-152. [CrossRef]

41. Baines, T.S.; Lightfoot, H.W.; Evans, S.; Neely, A.; Greenough, R.; Peppard, J.; Roy, R.; Shehab, E.; Braganza, A.; Tiwari, A.; et al. State-of-the-art in product-service systems. Proc. Inst. Mech. Eng. Part B J. Eng. Manuf. 2007, 221, 1543-1552. [CrossRef]

42. Merz, M.A.; He, Y.; Vargo, S.L. The evolving brand logic: A service-dominant logic perspective. J. Acad. Mark. Sci. 2009, 37, 328-344. [CrossRef]

43. Vargo, S.L.; Lusch, R.F.; Akaka, M.A.; He, Y. Service-dominant logic: A review and assessment. In Review of Marketing Research; Malhotra, N.K., Ed.; Emerald Group Publishing Limited: Bingley, UK, 2010; Volume 6, pp. 125-167.

44. Jacob, F.; Ulaga, W. The transition from product to service in business markets: An agenda for academic inquiry. Ind. Mark. Manag. 2008, 37, 247-253. [CrossRef]

45. Armstrong, C.M.; Niinimäki, K.; Kujala, S.; Karell, E.; Lang, C. Sustainable product-service systems for clothing: Exploring consumer perceptions of consumption alternatives in Finland. J. Clean. Prod. 2015, 97, 30-39. [CrossRef]

46. Chou, C.-J.; Chen, C.-W.; Conley, C. Creating sustainable value through service offerings. Res.-Technol. Manag. 2015, 58, 48-55.

47. Tukker, A. Product services for a resource-efficient and circular economy-A review. J. Clean. Prod. 2015, 97, 76-91. [CrossRef]

48. Annarelli, A.; Battistella, C.; Nonino, F. Product service system: A conceptual framework from a systematic review. J. Clean. Prod. 2016, 139, 1011-1032. [CrossRef]

49. Beuren, F.H.; Gomes Ferreira, M.G.; Cauchick Miguel, P.A. Product-service systems: A literature review on integrated products and services. J. Clean. Prod. 2013, 47, 222-231. [CrossRef]

50. Reim, W.; Parida, V.; Örtqvist, D. Product-service systems (pss) business models and tactics-A systematic literature review. J. Clean. Prod. 2015, 97, 61-75. [CrossRef]

51. Song, W.; Sakao, T. A customization-oriented framework for design of sustainable product/service system. J. Clean. Prod. 2017, 140, 1672-1685. [CrossRef]

52. Maxwell, D.; Sheate, W.; van der Vorst, R. Functional and systems aspects of the sustainable product and service development approach for industry. J. Clean. Prod. 2006, 14, 1466-1479. [CrossRef]

53. Morelli, N. Developing new product service systems (pss): Methodologies and operational tools. J. Clean. Prod. 2006, 14, 1495-1501. [CrossRef]

54. Geum, Y.; Park, Y. Designing the sustainable product-service integration: A product-service blueprint approach. J. Clean. Prod. 2011, 19, 1601-1614. [CrossRef]

55. Lim, C.-H.; Kim, K.-J.; Hong, Y.-S.; Park, K. Pss board: A structured tool for product-service system process visualization. J. Clean. Prod. 2012, 37, 42-53. [CrossRef]

56. The Chicago Architecture Foundation. Discover Design Handbook. Available online: https://www. Discoverdesign.Org/handbook (accessed on 7 May 2016).

57. Prince, M.J.; Felder, R.M. Inductive teaching and learning methods: Definitions, comparisons, and research bases. J. Eng. Educ. 2006, 95, 123-138. [CrossRef] 
58. Felder, R.M.; Silverman, L.K. Learning and teaching styles in journal of engineering education. J. Eng. Educ. 1988, 78, 674-681.

59. Lee, V.S. Teaching and Learning through Inquiry; Stylus Publishing: Sterling, VA, USA, 2004.

60. Boons, F.; Lüdeke-Freund, F. Business models for sustainable innovation: State-of-the-art and steps towards a research agenda. J. Clean. Prod. 2013, 45, 9-19. [CrossRef]

61. Du, Y.-L. From garbage-collection to resource management: The change of the spatial structure of the recycling system-the case study of Tainan city. Master's Thesis, National Taiwan Normal University, Taipei, Taiwan, 2000.

62. Malone, D.W. An introduction to the application of interpretive structural modeling. Proc. IEEE 1975, 63, 397-404. [CrossRef]

63. Cooper, R. Ethics and altruism: What constitutes socially responsible design? Des. Manag. Rev. 2005, 16, 10-18. [CrossRef]

64. Bramston, D.; Maycroft, N. Materials Experience: Chapter 9. Designing with Waste; Elsevier Science: New York, NY, USA, 2013.

65. Roy, R. Sustainable product-service systems. Futures 2000, 32, 289-299. [CrossRef]

66. Park, E.; Ohm, J.Y. Appropriate technology for sustainable ecosystems: Case studies of energy self-reliant villages and the future of the energy industry. Sustain. Dev. 2015, 23, 74-83. [CrossRef]

67. Ness, D. Sustainable product service systems: Potential to deliver business and social benefits with less resource use. In Green Technologies: Concepts, Methodologies, Tools and Applications; IGI Global: New York, NY, USA, 2011; pp. 539-554.

68. Patrício, L.; Fisk, R.P.; Cunha, J.F.E. Designing multi-interface service experiences: The service experience blueprint. J. Serv. Res. 2008, 10, 318-334. [CrossRef]

69. Goldstein, S.M.; Johnston, R.; Duffy, J.; Rao, J. The service concept: The missing link in service design research? J. Oper. Manag. 2002, 20, 121-134. [CrossRef]

70. Chase, R.; Bowen, D.E. Service quality and the service delivery system. In Service Quality: Multidisciplinary and Multi-National Perspectives; Lexington Books: Lexington, MA, USA, 1991; pp. 157-178.

71. Mentink, B. Circular Business Model Innovation: A Process Framework and a Tool for Business Model Innovation in a Circular Economy. Master's Thesis, Delft University of Technology, Delft, The Netherlands, 2014.

72. Bloom, P.N. How will consumer education affect consumer behavior? Adv. Consum. Res. 1976, 3, $208-212$.

73. Thefuntheory.com. Available online: www.thefuntheory.com (accessed on 8 June 2017).

74. Vezzoli, C.; Ceschin, F.; Diehl, J.C.; Kohtala, C. New design challenges to widely implement 'sustainable product-service systems'. J. Clean. Prod. 2015, 97, 1-12. [CrossRef] 